\title{
Identification of tsunami deposits and liquefaction features in the Gargano area (Italy): paleoseismological implication
}

\author{
Paolo Marco De Martini $\left({ }^{1}\right)$, Pierfrancesco Burrato $\left({ }^{1}\right)$, Daniela Pantosti $\left({ }^{1}\right)$, Alessandra Maramai $\left({ }^{1}\right)$, \\ Laura Graziani $\left({ }^{1}\right)$ and Hans Abramson $\left({ }^{2}\right)$ \\ (1) Istituto Nazionale di Geofisica e Vulcanologia, Roma, Italy \\ $\left(^{2}\right)$ Geomatrix Consultants, CA, U.S.A.
}

\begin{abstract}
The Gargano region (Southeastern Italy) was hit by a $M=6.8$ earthquake and inundated by a subsequent tsuna$\mathrm{mi}$ in 1627 . To better define the hazard in the region, we searched for evidence of this and prior earthquakes in the geologic record. We identified potential earthquake-related liquefaction features and tsunami deposits in the stratigraphic sequences of the marsh areas both north and south of the Gargano promontory. We recognized clear liquefaction features and possible tsunamigenic sands that can be related to the 1627 seismic event in irrigation ditch exposures and gouge cores along the Northern Gargano coast. In total, six potential tsunami sand deposits have been recognized in two areas located close to the northern and southern coasts of the Gargano promontory. However, ambiguous evidence comes from the paleontological analysis of these sands. Although fragments of marine shells have been found in the coarser portion of the sand samples, foraminifera and ostracods assemblages are typical of brackish water condition. Radiocarbon dating of three of these deposits from the Northern Gargano coast, near the town of Lesina, suggests an average recurrence interval of 1700 years for tsunami events in this area. Assuming that all the paleotsunamis are related to the same seismogenic source responsible for the 1627 earthquake, this average recurrence interval may be typical for that source. Radiocarbon dating of three sand layers observed on the southern coast, close to the city of Manfredonia, suggests that the average recurrence time for violent sea inundation there is about 1200 years.
\end{abstract}

Key words tsunami-liquefaction - Gargano 1627 earthquake

\section{Introduction}

The Gargano promontory and surrounding sea have been the objects of several recent geological and seismological studies. The promontory is clearly differentiated both geographical-

Mailing address: Dr. Paolo Marco De Martini, Istituto Nazionale di Geofisica e Vulcanologia, Via di Vigna Murata 605, 00143 Roma, Italy; demartini@ingv.it ly and as seismic activity rate from the foreland of the Apennines chain that bounds it to the west. Historical accounts from the 1627 earthquake (fig. 1), $I_{\max }=\mathrm{X}$ MCS (Mercalli-Cancani-Sieberg scale; Sieberg, 1930), describe extensive destruction with formation of cracks and liquefaction features from the Lesina area to San Severo and a strong tsunami that inundated the Northern Gargano coastland, also observed at the city of Manfredonia, to the east (fig. 1). Despite the fact that the fault responsible for the 1627 event has not yet been identified, this historical depiction suggests that the Gargano area is susceptible to tsunami inundation and liquefaction. Evidence of these effects 


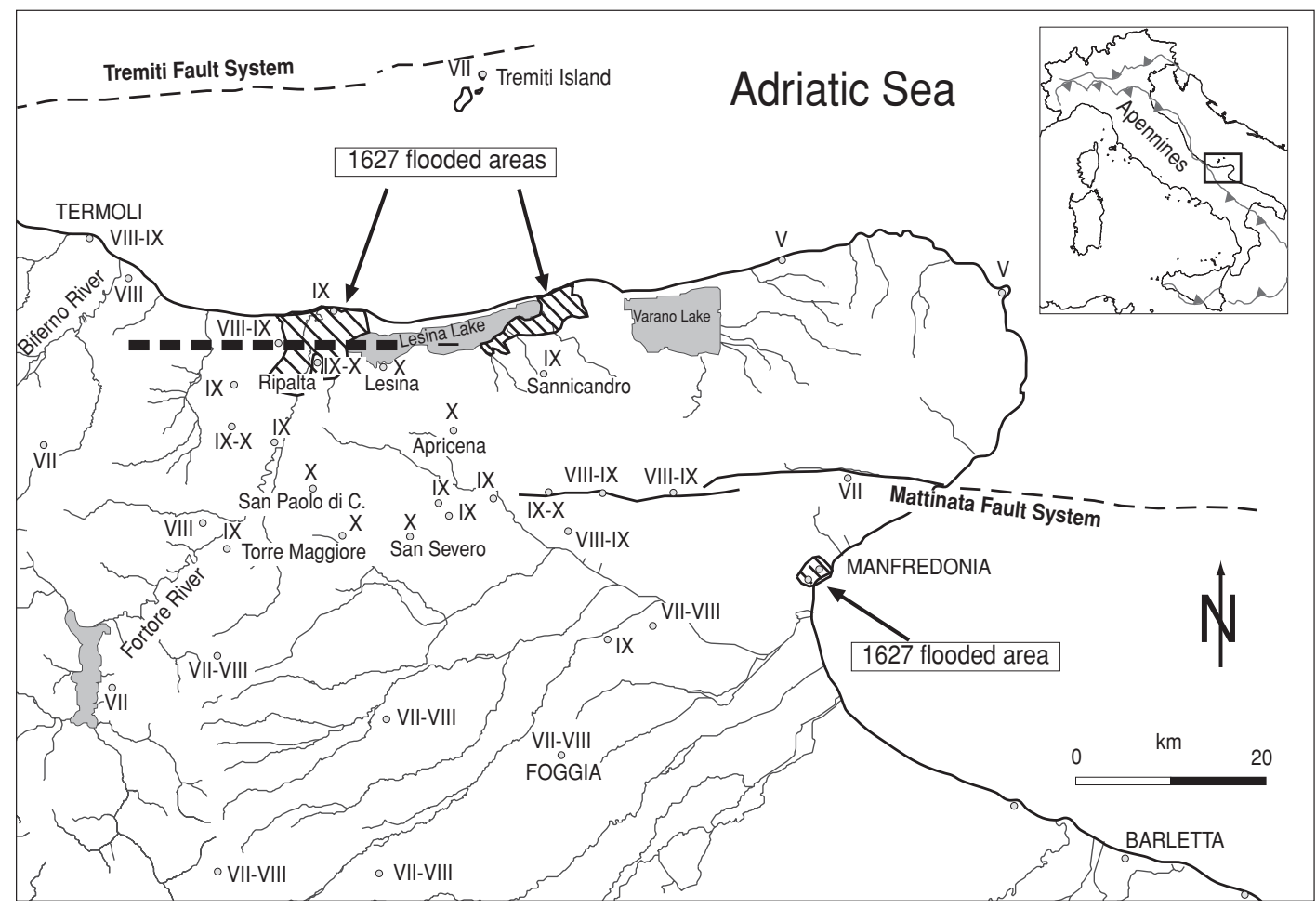

Fig. 1. Damage distribution of the June 30, 1627 earthquake. Intensities are plotted in roman numbers (Boschi et al., 2000). Areas inundated by the 1627 tsunami are also shown. The thick dashed line north of Lesina represents the best candidate for the source responsible for the 1627 earthquake and tsunami as proposed by Tinti and Piatanesi (1996).

may be preserved in coastal lowlands around Gargano. Reliable historical records of large earthquakes $(M>6)$ there reach $\sim 1000$ years into the past, but the geologic record preserved in coastal marshes and lakes may cover much of the Late Holocene. Based of geology, we could provide a longer time-frame to assess the tsunami recurrence and hazard of the study areas, an assessment now based on historical information only. However, a clear limitation of this approach is the intrinsic uncertainty about the earthquake source generating these secondary effects: it is not unusual to have tsunami waves and liquefaction features in Italy triggered by seismic events hundreds of kilometers away (Galli and Meloni, 1993; Tinti et al., 2002).
We studied the stratigraphy of coastal wetlands to characterize better the recurrence and distribution of tsunamis and liquefaction in the Gargano region. These features could likely be the result of the 1627 earthquake and previous Holocene events. In doing this, we studied the upper $5 \mathrm{~m}$ of stratigraphy in three marshes located on the northern and southeastern coast of the promontory (fig. 2). Preliminary micropalaeontological analysis has also been performed to describe the depositional environment of anomalous sand layers. Radiocarbon dating of nine samples (listed in table I) helped us reconstruct the inundation history of the studied areas. 
Table I. Measured and calibrated ages (according to Calib 4.3 by Stuiver et al., 1998a,b) of the samples collected in the ditches and cores.

\begin{tabular}{|c|c|c|c|c|c|c|}
\hline $\begin{array}{c}\text { Sample } \\
(*)\end{array}$ & Type & $\begin{array}{c}\text { Measured age } \\
\text { year BP } \\
\text { (corrected for } \\
\mathrm{C}^{13} / \mathrm{C}^{12} \text { ) }\end{array}$ & $\begin{array}{c}2 \sigma \text { cal age } \\
\text { years }\end{array}$ & $\begin{array}{l}\text { Proba- } \\
\text { bility }\end{array}$ & Lab & $\begin{array}{l}\text { Adopted interval } \\
\qquad(* *)\end{array}$ \\
\hline LD207 & Charcoal & $360 \pm 50$ & 1447-1638 A.D. & 1.000 & Beta & 1450-1640 A.D. \\
\hline LE1 & Charcoal & Modern & & & Beta & \\
\hline LE2 & Charcoal & $280 \pm 120$ & $\begin{array}{l}\text { 1438-1713 A.D. } \\
\text { 1716-1887 A.D. } \\
\text { 1911-1950 A.D. }\end{array}$ & $\begin{array}{l}0.663 \\
0.274 \\
0.064 \\
\end{array}$ & Beta & 1440-1890 A.D. \\
\hline TM5-RC2 & Charcoal & $4750 \pm 90$ & 3702-3355 B.C. & 1.00 & Beta & 3700-3350 B.C. \\
\hline TM5-RC3 & Charcoal & $4700 \pm 40$ & $\begin{array}{l}\text { 3631-3577 B.C. } \\
\text { 3571-3561 B.C. } \\
\text { 3538-3482 B.C. } \\
\text { 3475-3369 B.C. }\end{array}$ & $\begin{array}{l}0.199 \\
0.015 \\
0.229 \\
0.557\end{array}$ & Beta & 3630-3370 B.C. \\
\hline SIP-D5-RC3 & Charcoal & $1710 \pm 40$ & 244-416 A.D. & 1.000 & C.A.I.S. & 240-420 A.D. \\
\hline SIP-D7-RC2 & Charcoal & $1650 \pm 40$ & $\begin{array}{l}\text { 261-280 A.D. } \\
\text { 293-296 A.D. } \\
\text { 323-473 A.D. } \\
\text { 477-531 A.D. }\end{array}$ & $\begin{array}{l}0.057 \\
0.005 \\
0.820 \\
0.118\end{array}$ & C.A.I.S. & 320-530 A.D. \\
\hline SI9-A2RC1 & Charcoal & $3250 \pm 40$ & $\begin{array}{l}\text { 1676-1674 B.C. } \\
\text { 1620-1430 B.C. }\end{array}$ & $\begin{array}{l}0.005 \\
0.995\end{array}$ & Beta & 1620-1430 B.C. \\
\hline SI9-A2RC2 & Charcoal & $3630 \pm 40$ & $\begin{array}{l}\text { 2135-2079 B.C. } \\
\text { 2054-1884 B.C. }\end{array}$ & $\begin{array}{l}0.152 \\
0.848\end{array}$ & Beta & 2130-1880 B.C. \\
\hline
\end{tabular}

(*) The code of the sample reflects the site where it was collected. (**) To simplify the discussion in the text and figures ages are reported adjusted to the nearest decade and with one single range including all the main intervals with probability larger than 0.100 .

\section{Seismotectonic framework}

\subsection{Geological-structural setting}

The Gargano promontory is located on the Southern Adriatic coast of the Italian Peninsula and is considered part of the Adriatic block (Adria): one of the microplates identified in the Central Mediterranean at the collisional border of the European and African plates (McKenzie, 1972). Adria is an elongated continental block which extends from the Po Plain southward to the Adriatic Basin. Lort (1971) originally identified the margins of this Adriatic microplate based on seismicity patterns. Many authors have subsequently interpreted this plate as a single, nearly aseismic, rigid block (Mantovani et al., 1985, 1993; Anderson and Jackson, 1987) being overridden (or subducted) along three of its margins: underthrusting the Hellenides and the Di- narides to the east, the Southern Alps to the north, and the Apennines to the west.

Some authors (Console et al., 1989, 1993; Favali et al., 1990, 1992, 1993) suggest complex heterogeneities or lithospheric breaks in this area based on more recent structural data, seismic profiles and seismicity. In particular, they identified two active regional strike-slip discontinuities crossing the Adriatic Sea at the latitude of the Gargano promontory (Finetti, 1984; Favali et al., 1992; Chilovi et al., 2000): the Tremiti Fault and the Mattinata Fault systems (fig. 2).

The Gargano promontory, a structural high area where Mesozoic strata rise to about $1000 \mathrm{~m}$ above sea level (a.s.1.), is characterized by a positive Bouguer gravity anomaly (Finetti and Morelli, 1973). The presence of several Quaternary marine terraces indicates substantial Quaternary uplift of the promon- 


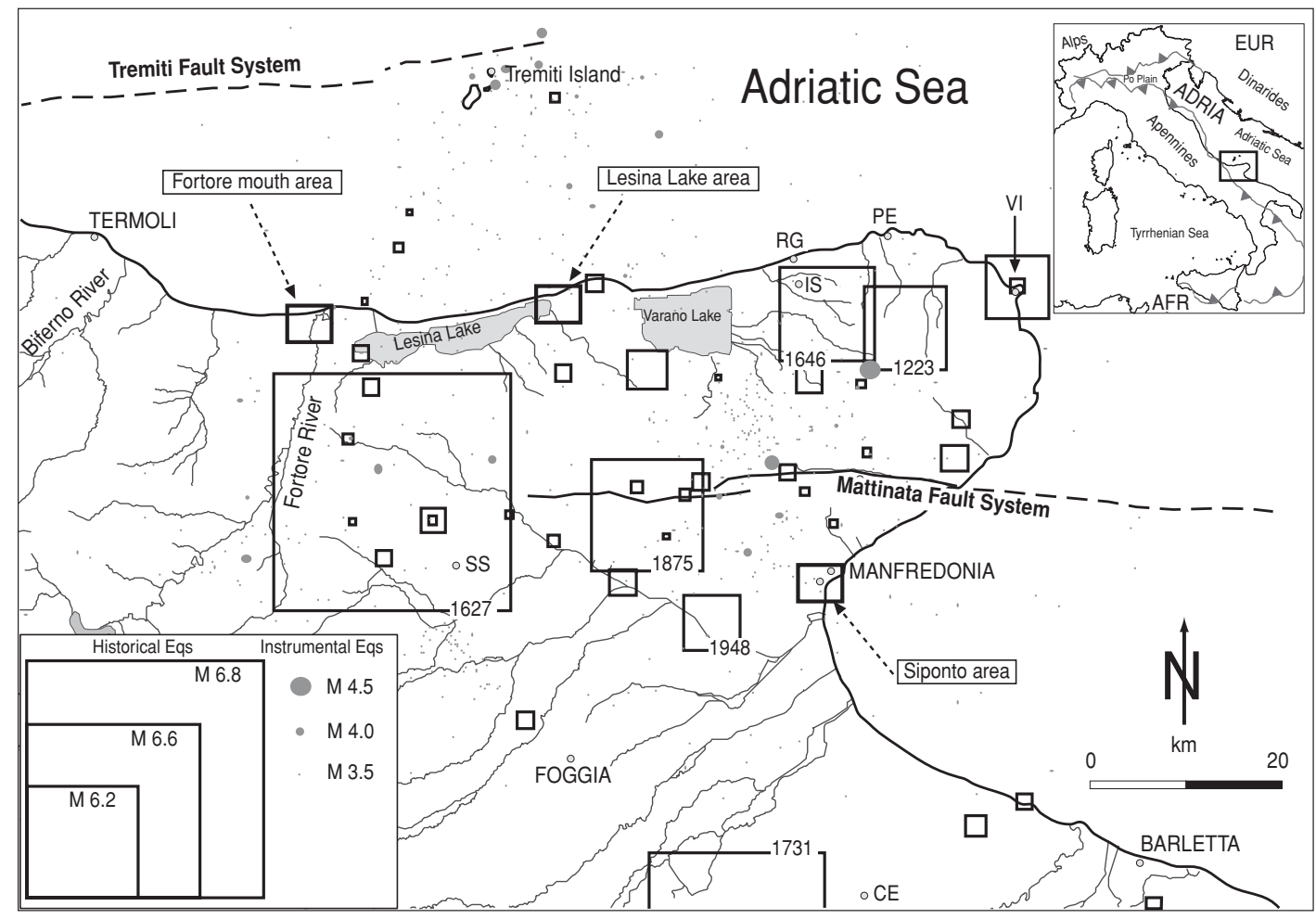

Fig. 2. Historical (CPTI Working Group, 1999) and instrumental (INGV Monthly Bulletin, 1985-2000) seismicity of the Gargano region. Thick rectangles show the location of the areas investigated in the present study. Abbreviations: RG - Rodi Garganico; IS - Ischitella; PE - Peschici; CE - Cerignola; SS - San Severo; VI - Vieste. Inset in the upper right shows the location of the Gargano region (thick rectangle).

tory (Checchia Rispoli, 1916; Doglioni, 1994). Structural and geomorphic analyses (Favali $e t$ al., 1992; Piccardi, 1998; Salvini et al., 1999, and references therein) show that the dominant deformation structures are the regional E-W strike slip Mattinata Fault System together with secondary NW-SE strike slip and dip slip faults. In particular, the Mattinata Fault experienced a reversal from Late Miocene to Early Pliocene left-lateral strike slip to right-lateral strike slip movement since Late Pliocene (Chilovi et al., 2000). Regional CMT solutions (RCMT, 2002) of the October 31 and November $12002 M_{w}=5.7$ earthquakes, occurred $50 \mathrm{~km}$ far to the west of the Mattinata Fault, showed also the same rightlateral sense of movement.

\subsection{Historical and instrumental seismicity}

Despite its location in the supposedly inactive foreland of the Southern Apennine fold and thrust belt, the Gargano promontory has been affected by strong local earthquakes in the past (fig. 2). Historical seismic catalogues (Postpischl, 1985; ING, 1991; Boschi et al., 2000) include a large number of earthquakes in the last millennium. Some earthquakes, in particular those in 1223 ( $I_{\max }$ IX), $1627\left(I_{\max } \mathrm{X}\right), 1646\left(I_{\max } \mathrm{IX}-\mathrm{X}\right), 1731\left(I_{\max }\right.$ IX), 1875 ( $I_{\max }$ VII-VIII) and 1948 ( $I_{\max }$ VIIVIII), were characterized by significant damage. Moreover, many of these events were followed by aftershock sequences, some of which lasted over one year (Baratta, 1901). 
The 1223 shock hit the southeast coastline between Siponto and Vieste causing severe damage to both towns. The 1627 earthquake, the largest seismic event ever in the Gargano region, struck a wide area from the Lesina Lake to San Severo, west of the promontory. A precise description of this earthquake is included in the following section. During the 1646 earthquake, the whole Gargano suffered severe damage and in particular Vieste, Rodi Garganico, Ischitella and Peschici, located on the northeastern edge of the promontory, were completely ruined, suggesting a likely offshore location of the epicenter. The 1731 earthquake was probably located south of Gargano, as most of the destruction occurred in Foggia and Cerignola (IX MCS), while in the Gargano area only Siponto and Manfredonia had minor damage. After this shock, however, a sudden sea rise, that nearly wrecked some boats, was reported along the coast between Siponto and Barletta (south of the Gargano promontory), suggesting the 1731 earthquake triggered a tsunami (Tinti et al., 2002). The 1875 earthquake has been associated with the western section of the Mattinata Fault System. (Valensise and Pantosti, 2001). This interpretation indicates that the Mattinata Fault can produce large earthquakes and thus its activity is not limited to microseismicity as previously thought. Finally, the 1948 earthquake, characterized by three major shocks in three days, was felt in a wide area and produced maximum damage along the eastern section of the Mattinata Fault System, where it was probably located.

The Italian seismic network, implemented in the past twenty years, shows seismic activity offshore near Gargano localized along $\sim$ E-W trending structures. Detailed studies of three seismic sequences in the Southern Adriatic Sea between 1986 and 1990 (Console et al., 1993) suggest their association with the Tremiti Fault. This implies that this offshore structure is seismically active. Thus, both the Tremiti Fault and the Mattinata Fault System (see previous paragraph), should be considered major candidates for the location of large earthquakes and related tsunamis.

\subsection{The July 30, 1627 earthquake}

On July 30, 1627 around midday a disastrous earthquake $\left(I_{\max }=\mathrm{X}\right.$ MCS $)$ hit the Gargano promontory, with the strongest shaking concentrated in the northern coastal area between Lesina and Ripalta (fig. 1). The shock was followed by a strong tsunami and four large aftershocks, the first one occurring about $15 \mathrm{~min}$ after the main shock. Many contemporary sources described the event, providing a detailed picture of the extensive destruction and many casualties. Figure 1 shows the distribution of the macroseismic intensities (Boschi et al., 2000), and the location of the flooded areas. The most severely affected villages were Apricena, Lesina, San Paolo di Civitate, San Severo and Torre Maggiore, where most buildings were totally destroyed. The earthquake left more than 5000 victims and was felt in a very broad area, as far as the Central Apennines and Sicily. It caused cracks on the ground surface, subsidence, flooding, and gas emissions along the Fortore River accompanied by modified active river channels and dried lakes. However no clear evidence for surface faulting was found. The damage distribution (Boschi et al., 2000; fig. 1) from which the macroseismic epicenter (fig. 2) is derived does not help resolving the ambiguity of the earthquake source location and leaves open the possibility of an offshore source.

A significant tsunami, intensity 5 on the Sieberg-Ambraseys scale (Ambraseys, 1962) which means «very strong tsunami», occurred after the main shock. The tsunami was particularly violent on the northern coast of Gargano, between the Fortore River and the coastal plane north of Sannicandro, around the Lesina Lake. The lake, approximately $20 \mathrm{~km}$ long and $4 \mathrm{~km}$ wide, is separated from the sea by a narrow sand spit. Few artificial channels through the spit connect the lake to the sea. Eyewitness accounts report that Lesina Lake completely dried for many hours after the shock and many fish were stranded far from water. A coeval drawing by De Poardi (1627; fig. 3) depicts this phenomenon. Contemporary reports describe an initial sea withdrawal of about three kilometers, followed by a great inundation that extended some length inland. According to Ballerani (1627) seawater 


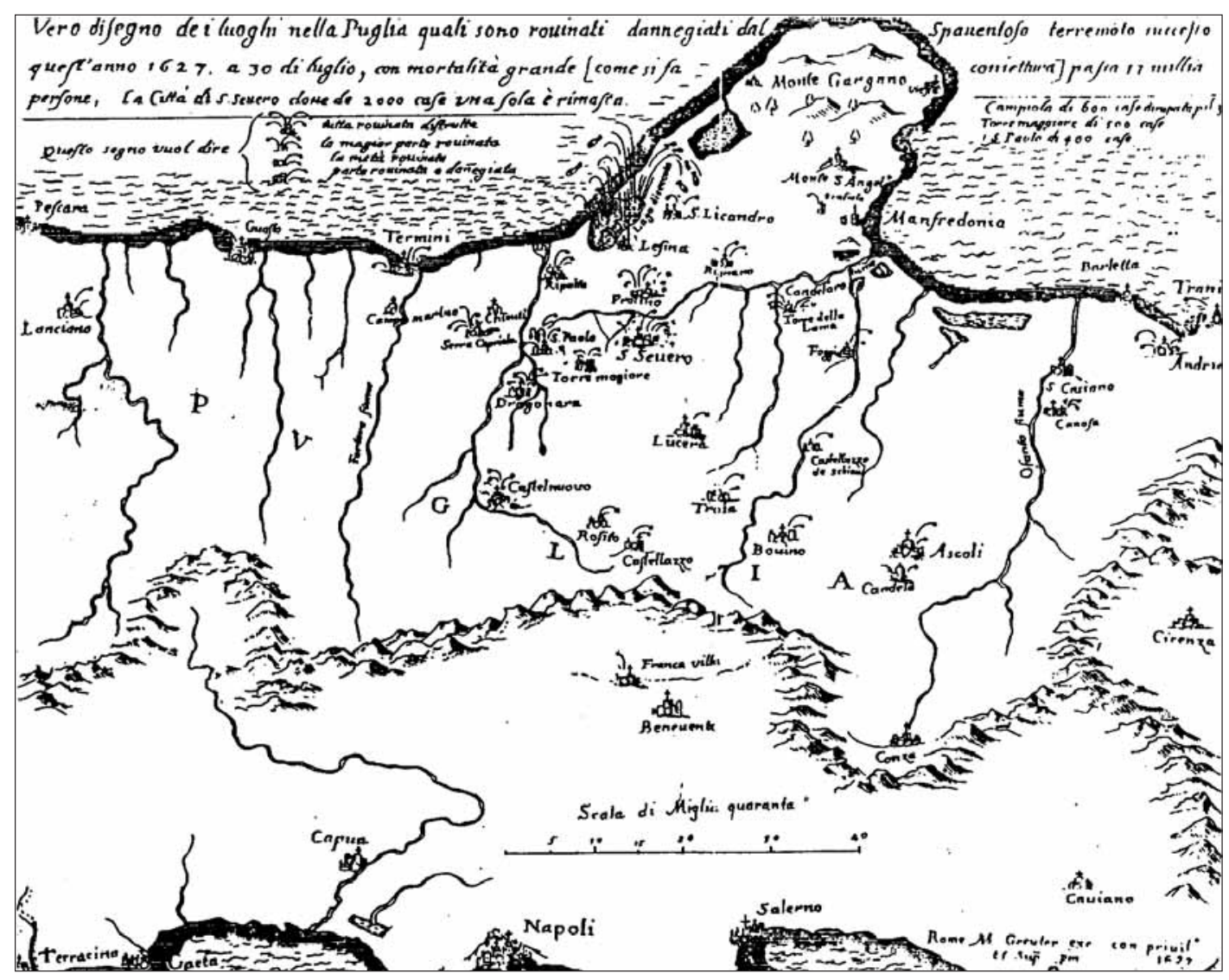

Fig. 3. Drawing from De Poardi (1627) describing some effects of the 1627. Note that fishes are drown as the rows out from the Lesina Lake. This map can be considered as the ancestor of modern macroseismic maps, since the author represented with various symbols cities which sustained different levels of damage.

flooded the village of Lesina and the victims were «uncountable». No distinction was made between casualties directly related to the earthquake and those caused by the tsunami. Less severe tsunami effects were reported over a very wide area. At the mouth of the Saro River (today called Foro, about $60 \mathrm{~km}$ north of Termoli), a sea withdrawal of about $90 \mathrm{~m}$ was observed (Antinori, 1782). In Manfredonia, on the southern coasts of Gargano, the waves reached the city walls, about $2.5 \mathrm{~m}$ above the mean sea level (Cerqua, 1627). Accounts of the earthquake are much more abundant and detailed than those concerning the tsunami, precluding assessments of wave height, flow velocity, and run-up limit based solely on historical reports. One potential explanation for this is that most people lived well inland during the 17th century, and the marshy lowlands around Lesina Lake were almost uninhabited.

\section{Observations and data collection}

As already discussed, the 1627 contemporary chronicles clearly state that the July 30 
earthquake produced a tsunami wave that flooded the northern coast of the Gargano promontory and the Manfredonia harbor to the east, along with liquefaction features over a wide area. Field surveys of areas affected by modern tsunamis show that their effects may be preserved in the geologic record. The most prominent of these effects are erosion and transport of beach sand and debris from the beach with subsequent deposition inland where they may be preserved in marsh or lacustrine sediments (Bourgeois and Reinhart, 1989; Dawson et al., 1991a,b; Dawson et al., 1995).

To investigate the existence of these geologic records in the Gargano area we performed a detailed interpretation of aerial photographs to identify coastal wetlands that showed little evidence for anthropogenic modification. If these wetlands show a relatively continuous depositional history over the Late Holocene with few and short episodes of erosion, they have a high probability of preserving deposits from tsunamis or liquefaction features. We identified marshes at the Fortore River mouth in the eastern part of the Lesina Lake and in the Siponto farmlands (fig. 2). These are considered test areas where the features that formed during the 1627 and possibly older earthquakes may have been preserved in the stratigraphic sequence.

\subsection{Fortore mouth area}

The Fortore River flows, with a NNE direction, from the Southern Apennines and abuts the Adriatic Sea just west of the Gargano promontory. The estuarine zone around its mouth is about $2.5 \mathrm{~km}$ wide, and includes several abandoned channels. Much of this land is currently used for agriculture purposes (fig. 4). The most impressive description of the 1627 tsunami wave, reported by contemporary chronicles, refers to

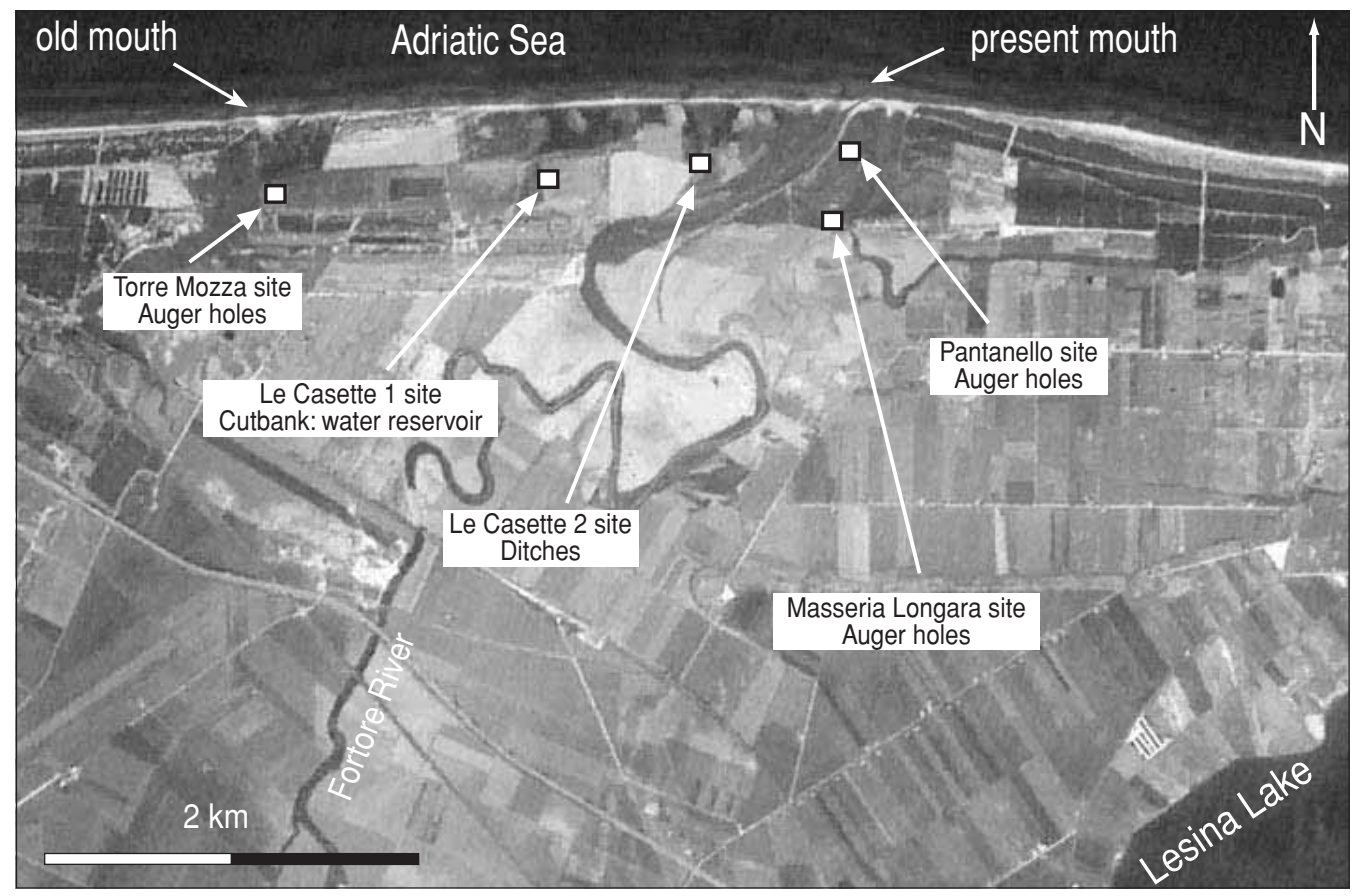

Fig. 4. Spot image (DOI-10M - National Imagery and Mapping Agency: contains data (C) CNES/SPOT image 1992-1994 copyright) of the Fortore mouth area with location of the investigated sites. 
this locality. However, several sites near the Fortore River mouth lack significant evidence of tsunami deposits. Auger holes from two sites east of the Fortore mouth, Pantanello and Masseria Longara sites (fig. 4), revealed mostly sandy and silty fine sand overbank fluvial deposits extending up to the holes end at 2-2.5 m. Weakly developed soils cover both sequences. West of the Fortore mouth (fig. 4) auger holes and cut-banks show undisturbed stratigraphy at two other sites. At Torre Mozza approximately $60-80 \mathrm{~cm}$ of thick, dark, loose mud overlies well sorted mediumgrained sand extending to a depth of 2-2.5 m. At Le Casette 1 an undisturbed sequence of alternating fine sand and silty clay is exposed in cutbanks of a water hole.

At Le Casette 2 site distinct sand dikes and ball and pillar structures in a stratigraphy of interbedded sand, silt, and clay signify earthquakeinduced liquefaction (fig. 4). The upper $1.5 \mathrm{~m}$ at this site consist primarily of bluish-gray silty clay with planar beds of sand and silt ranging from $<1$ $\mathrm{cm}$ to over $20 \mathrm{~cm}$ thick. These beds are typically planar, horizontal, and show no internal grain size variation. One convoluted layer, however, is exposed at depths from 25 to $40 \mathrm{~cm}$ in a $50 \mathrm{~m}$ reach of the cut-banks of an abandoned channel now used as irrigation ditch. It consists primarily of very fine to medium grained sand with thin silty layers, and presents a total thickness ranging from 10 to $20 \mathrm{~cm}$. Clasts of gray clay, that are sometimes angular and sometimes stretched parallel to the convoluted upper and lower contacts, are entrained in the sand and silt. This layer is graded to finest material both toward its top and bottom. The presence of coarsest material in the middle suggests flow of liquefied sand within it. Both the upper and lower contacts of this layer are contorted into «ball and pillar structures», common in liquefied sand (Obermeier, 1996; Obermeier and Pond, 1999).

The most convincing evidence for liquefaction, however, are the vertical sand dikes that extrude from the top of this layer, crosscut bedding and rising to within $5-10 \mathrm{~cm}$ of the marsh surface where they are overprinted by bioturbation and modern loamy soil (fig. 5). These dikes are very thin (up to $3 \mathrm{~cm}$ thick) and planar but locally are

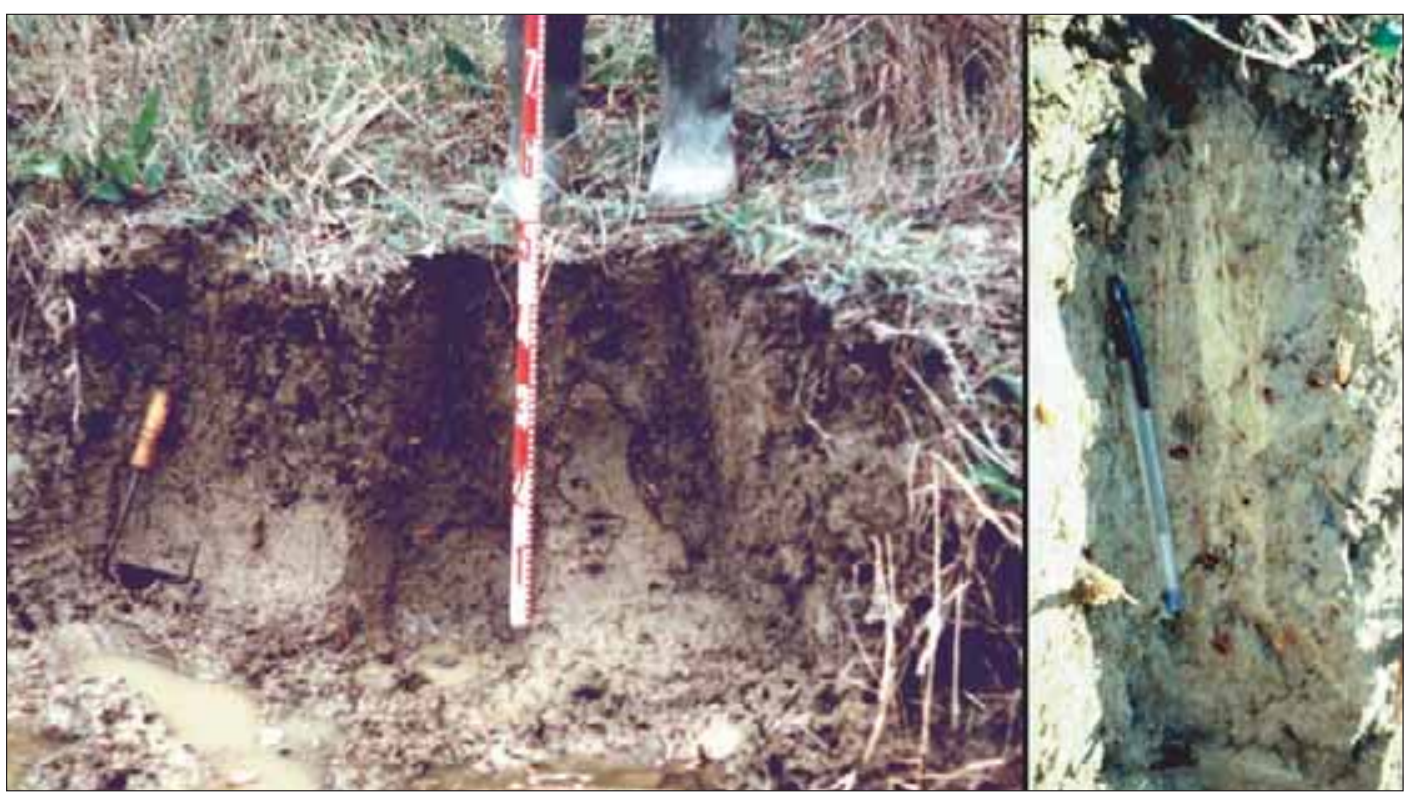

Fig. 5. Pictures of the sand dikes observed on the cutbanks of an abandoned channel at Le Casette 2 site. 


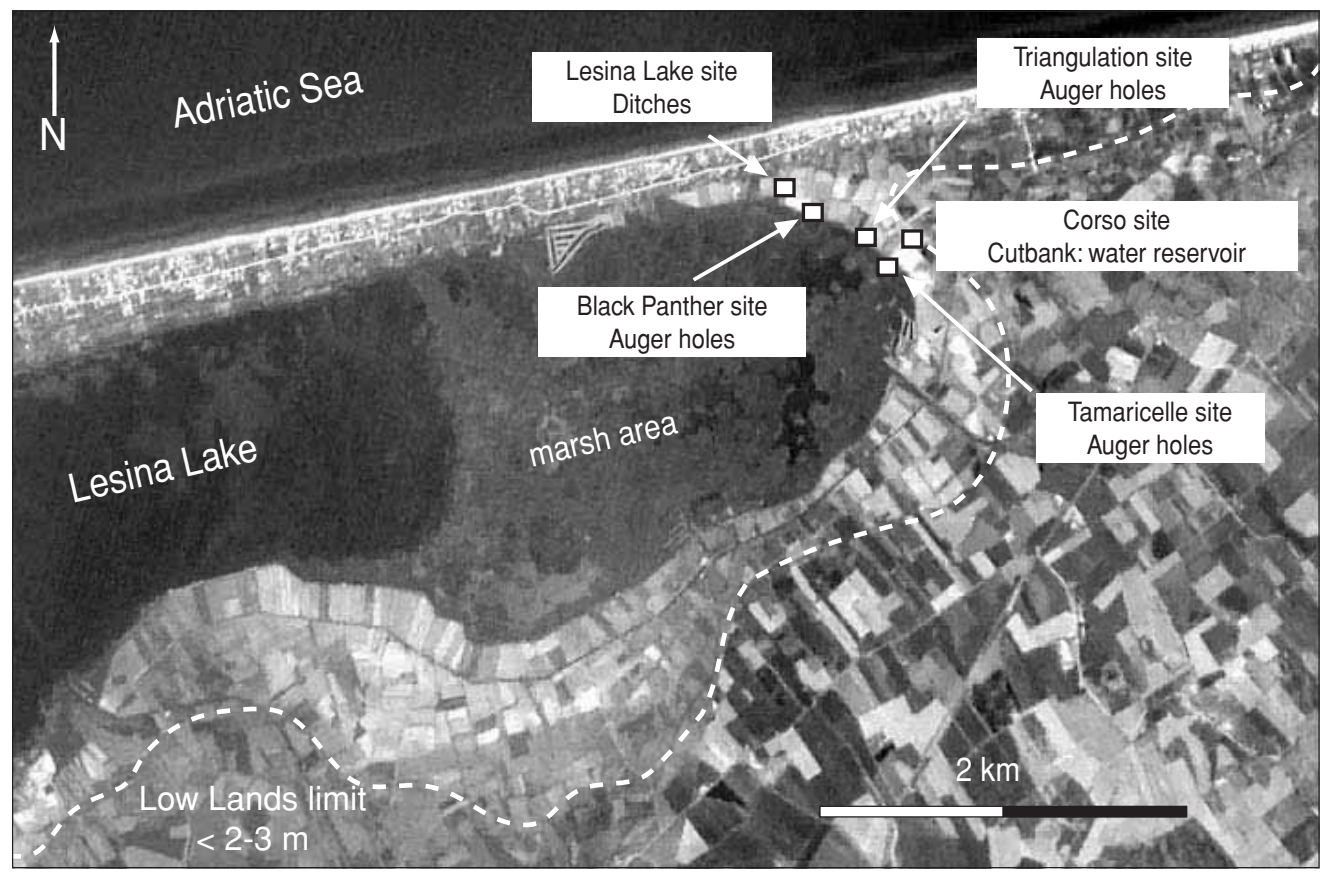

Fig. 6. Spot image (DOI-10M - National Imagery and Mapping Agency: contains data (C) CNES/SPOT image 1992-1994 copyright) of the Lesina Lake area with location the investigated sites. The dashed white line encircles the low lands probably inundated in 1627.

thicker $(5-10 \mathrm{~cm})$ and bulbous. Unfortunately no datable material has been found to constrain the age of the liquefaction event. Taking into account that the upper termination of the sand dikes reaches the modern soil, we suggest that this liquefaction is related to the 1627 earthquake, the local best candidate for inducing strong shaking and high pick ground acceleration values.

More liquefaction features are exposed on the cut-banks of an abandoned estuary channel that parallels the modern beach roughly $300 \mathrm{~m}$ inland.

The modern beach shows signs of rapid retreat. Clayey marsh deposits are being exhumed by wave erosion and retreat of the beach along a $2.5 \mathrm{~km}$ reach around the Fortore estuary. A house built in the 1970's $2 \mathrm{~km}$ west of the river mouth is crumbling into the water due to wave erosion. Finally, there is virtually no natural dune around the Fortore River mouth to protect against coastal erosion. For the above reasons, we suspect there may have been a delta associated with the Fortore
River at the time of the earthquake and that the shoreline was probably much further out. All these considerations on the rapid modification occurring at this site could help explaining the lack of evidence for tsunami deposits.

\subsection{Lesina Lake area}

Contemporary chronicles reported that the 1627 earthquake produced a huge wave that inundated the country side of Sannicandro. This city lies at $225 \mathrm{~m}$ a.s.1., about $9 \mathrm{~km}$ inland on the northern foothills of the Gargano promontory, and dominates the Eastern Lesina Lake plain. We selected a $5 \mathrm{~km}^{2}$ marshy area located at the lake's northeastern edge (fig. 6), where we studied five sites located as far as $1 \mathrm{~km}$ inland from the modern shoreline. The marshy eastern end of Lesina Lake and the low, narrow sand spit that separates it from the sea combine 

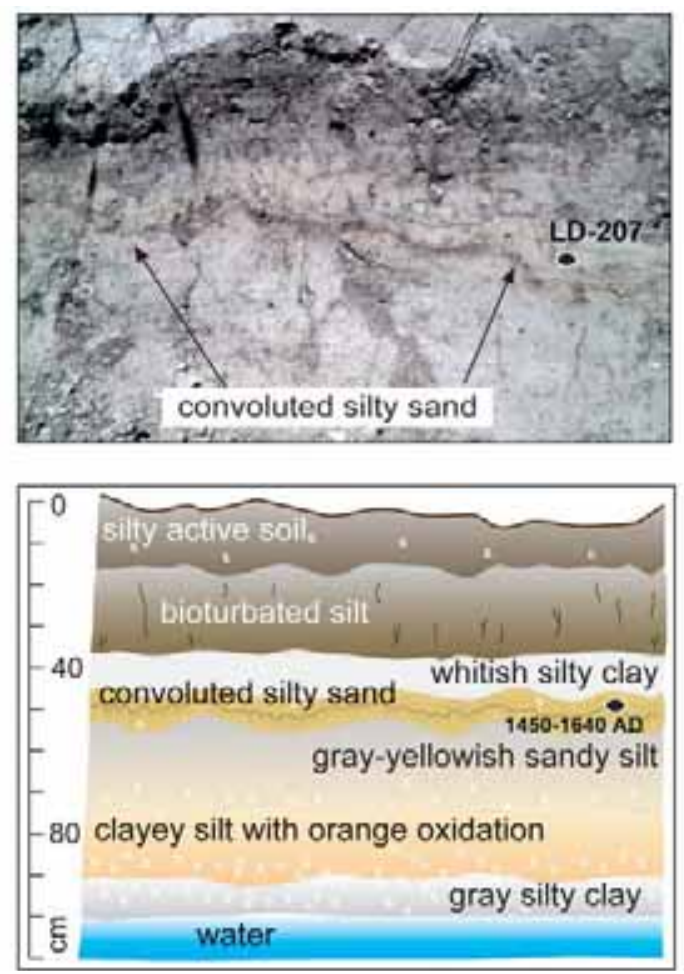

Fig. 7. Lesina Lake site: picture of the convoluted layer (above) and simplified sketch of the upper $1 \mathrm{~m}$ stratigraphy studied in the ditches (below). The location of one charcoal sample is also plotted with a black circle.

to create conditions favorable for deposition and preservation of tsunami deposits.

Irrigation ditches in reclaimed marsh land expose stratigraphy in the northeastern portion of Lesina Lake between the sea and the regions flooded by the tsunami in 1627 . The ditches on the inland edge of the sand spit are oriented perpendicular to the coastline, extending roughly 3-400 $\mathrm{m}$ inland. The ground level around these ditches is currently lower than the water level of the lake and they are protected from flooding by an artificial dike. A convoluted layer similar to that found at the Fortore River mouth shows evidence of either liquefaction or syn-depositional soft-sediment deformation at this site. This very fine, tan silty sand layer locates from 40 to $60 \mathrm{~cm}$ below the modern ground surface (fig. 7). The convoluted layer contains stretched and broken clay clasts in a matrix of fine grained sand with horizontal flow structures around them. The sand is finer on the upper and lower edges of the layer and coarser in the middle, features common in liquefied sand deposits (Obermeier, 1996; Obermeier and Pond, 1999). Radiocarbon dating of a piece of charcoal from the top of this layer yields an age of 1450-1640 A.D., providing a limiting maximum age for the disruption (Sample LD207 in table I). An additional exposure from the Corso site $(\sim 700 \mathrm{~m}$ east and $\sim 750 \mathrm{~m}$ from the shoreline) revealed a $2 \mathrm{~cm}$ thick sand layer $1 \mathrm{~m}$ below the surface that may correlate to this convoluted layer.

To assess stratigraphy in the marsh immediately south of the ditches, we collected 18 gouge cores that penetrated up to $5 \mathrm{~m}$ deep. Sampling sites spaced along the perimeter of Lesina Lake (fig. 6) included: 8 cores in the $\sim 2000 \mathrm{~m}^{2}$ surrounding the Black Panther site, 2 at the Triangulation site, and 8 in the $\sim 2000 \mathrm{~m}^{2}$ surrounding the Tamaricelle site.

The stratigraphy revealed by these cores is remarkably uniform. Figure 8 shows the log of a representative core, BPAU2, from the Black Panther site about $100 \mathrm{~m}$ south of the ditches. The general stratigraphy observed at this east end of Lesina Lake consists primarily of peat and mud with a few thicker clayey and sandy silt intervals. Most cores hit refusal below $4 \mathrm{~m}$ depth in a dark gray, hard, sticky clay layer. This stratigraphy is punctuated by 3 anomalous sandy or coarse silty layers that indicate high energy deposition and/or marked changes in depositional environment. We think these «disturbance layers» are potentially deposits from the 1627 tsunami and two earlier waves. We refer to the events depositing these disturbance layers as Events L1, L2, and L3 where Event L1 represents the most recent and Event L3 the oldest deposition.

The uppermost disturbance layer, found at a depth of $70-90 \mathrm{~cm}$, is $\sim 10 \mathrm{~cm}$ thick, light brown, medium to fine sand, with shell fragments concentrated at the bottom. The second is $\sim 3-5 \mathrm{~cm}$ thick, gray, fine sand with abundant shell fragments, lying approximately $270 \mathrm{~cm}$ 


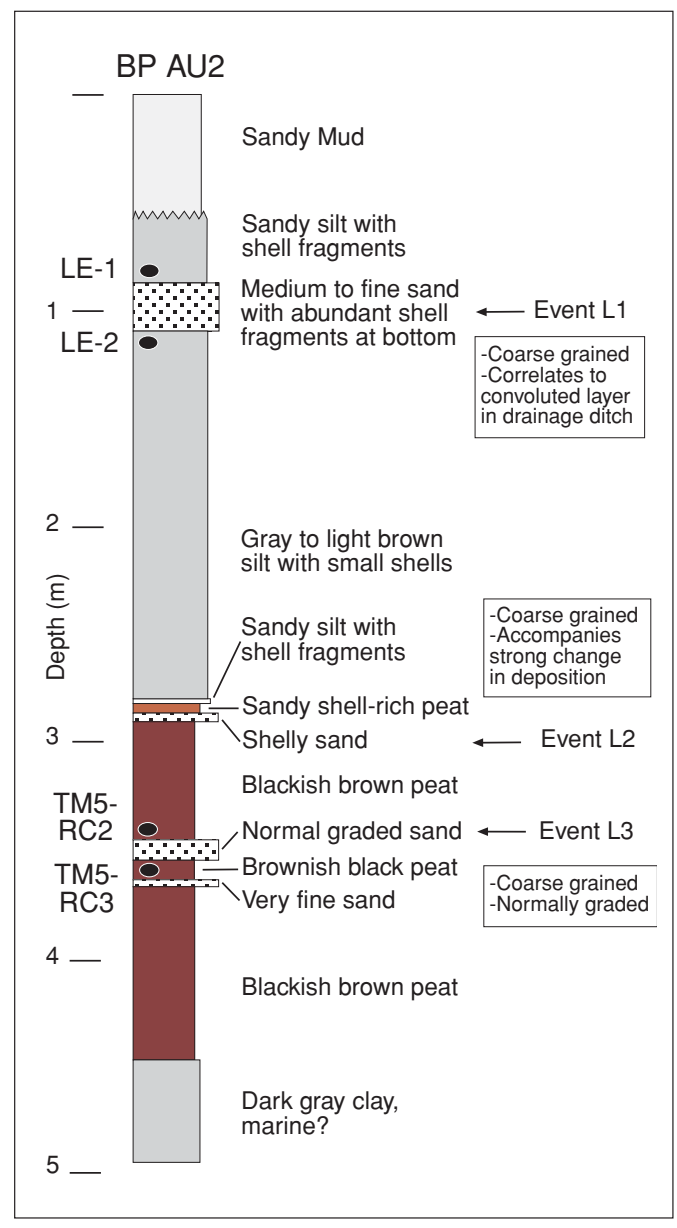

Fig. 8. Core BPAU2 log from Lesina Lake area. The location of four charcoal samples is also plotted with a black circle.

deep. The third layer is $\sim 3-5 \mathrm{~cm}$ thick, sandy silt that is normally graded (coarser at the bottom, where shell fragments have been found) and lies about $340 \mathrm{~cm}$ below the surface (fig. 9a).

Each disturbance stratum has a sharp lower contact, contains shell detritus and sediments coarser than that above and below it. This implies rapid change to high energy deposition, consistent with that from an inundating tsunami wave. One of the three layers accompanies transition from marsh peat (below) to gray silty mud (above), recording also a sudden change in depositional environment. All three layers contain sand: a common element of tsunami deposits (Bourgeois and Reinhart, 1989; Clague et al., 1994; Minoura et al., 1996; Benson et al., 1997).

Four radiocarbon dates constrain the time of deposition of two disturbance layers (samples LE1, LE2, TM5-RC2, TM5-RC3 in table I). Dating suggests that the uppermost disturbance layer (L1) is younger than 1440-1890 A.D., with the older age statistically preferred, and the lowermost sand (L3) was deposited in the interval 3630-3350 B.C.

Other sandy layers occur in the stratigraphy of Lesina Lake area that are not interpreted as tsunami deposits. They are either too localized (they occur only in one core), lack of sharp contacts, are much thicker than expected for a tsunami deposit so far from the major source of sand (the beach), or do not accom-
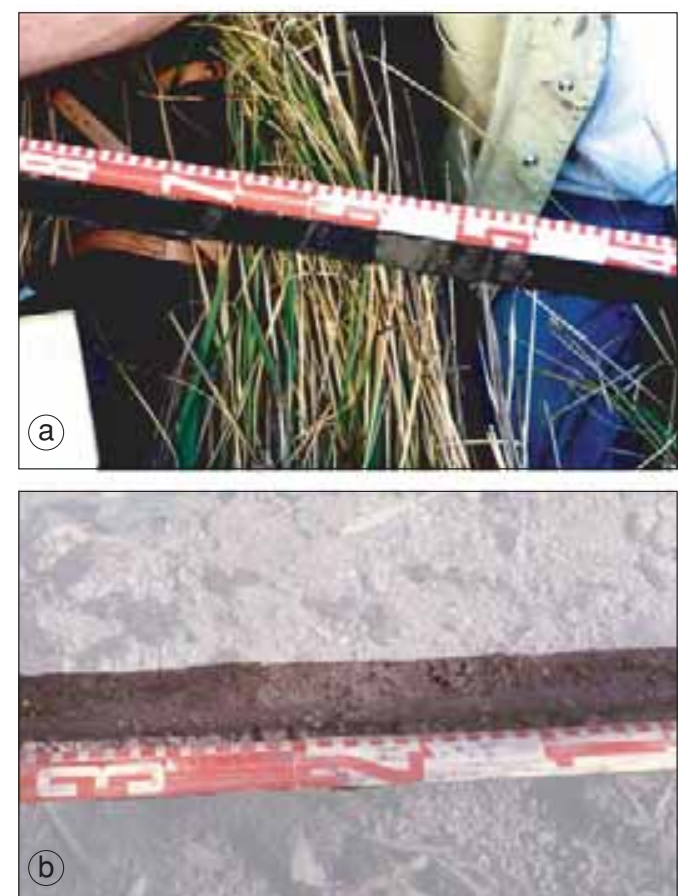

Fig. 9a,b. a) Picture of the Event L3 sand found at Black Panther site; b) picture of Event S3 sand collected at Mr. Paolo's site. 
pany a change in depositional environment. These sand layers may be channel deposits, colluvial material that has washed down the neighboring hillside, or simply longer term environmental changes in the lake, such as the opening of the sand spit.

\subsection{Siponto area}

The area South of Siponto, that was once the seaport of the ancient Roman town of Siponto, was naturally filled with sediment and is today represented by a low lying area extending inland roughly $1.0-1.3 \mathrm{~km}$ (fig. 10). This $0.5 \mathrm{~km}^{2}$ region is currently used for farming and is dissected by a dense network of irrigation ditches draining the abundant spring water away.
We investigated stratigraphy of exposures in irrigation ditches throughout the region, but we mostly focused on two locations, $\mathrm{Mr}$. Paolo and Siponto sites. There the water was at least $1.0-1.3 \mathrm{~m}$ below the ground surface allowing to study the upper part of the stratigraphy. At Mr. Paolo site we also collected gouge cores at 8 locations, penetrating approximately $5 \mathrm{~m}$.

As exposed in irrigation ditches and in gouge cores, the observed stratigraphy consists almost entirely of brownish black peat. The peat has gastropod fossils scattered throughout and chunks of tan tufa. Near the surface several intact plant fossils are preserved in the peat, while lower in the stratigraphy peat is more decomposed and contains muddy and sandy layers. The peat is capped by $0.5-0.7 \mathrm{~m}$ of clayey loam. At a depth of roughly 4.5-5 m, peat over-

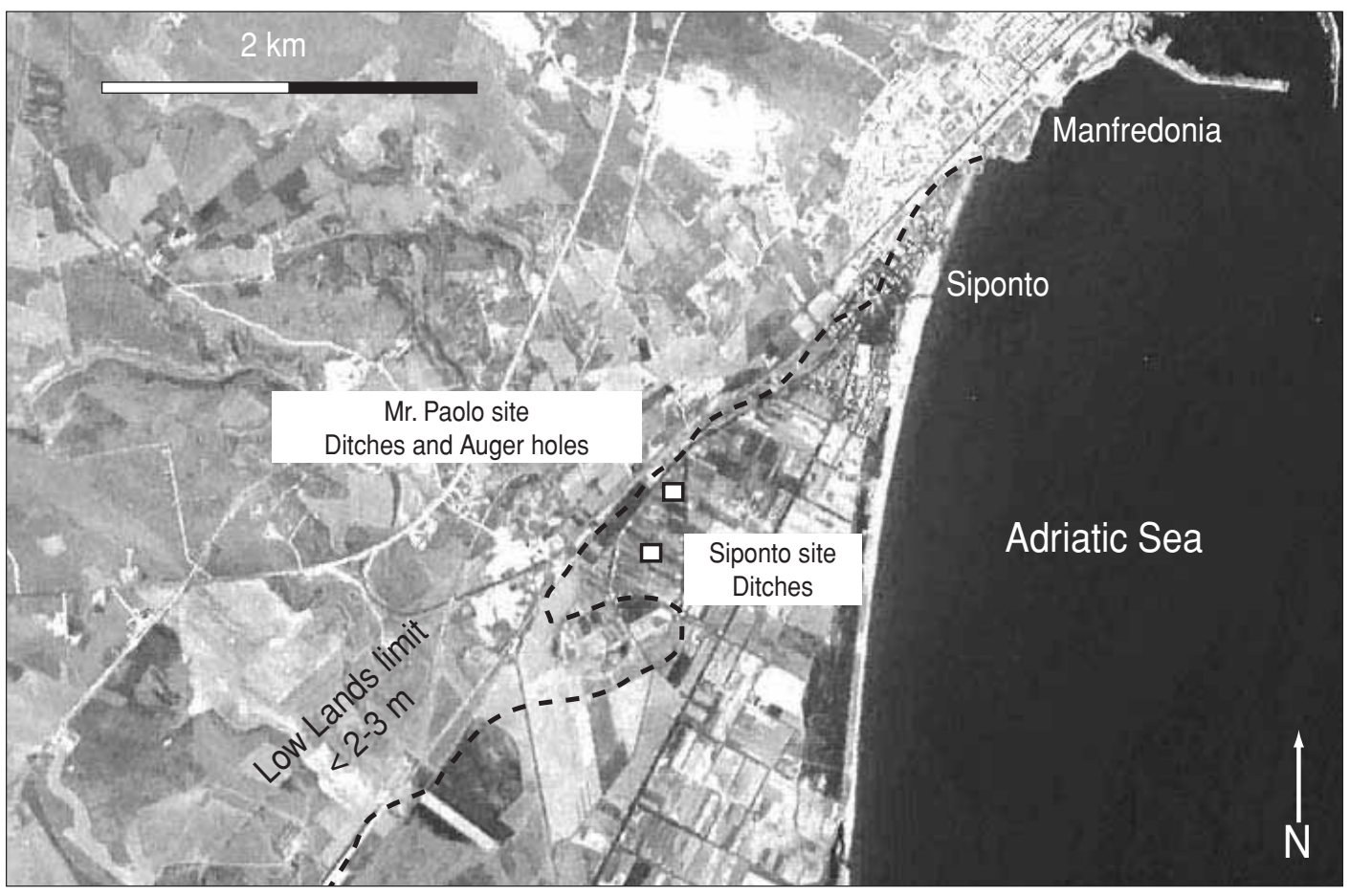

Fig. 10. Spot image (DOI-10M - National Imagery and Mapping Agency: contains data (C) CNES/SPOT image 1992-1994 copyright) of the Siponto area with the sites investigated in the present work. The dashed black line encircles the low lands that could probably be inundated by tsunami waves. 
lies a hard gray pebbly clay that gouge cores cannot penetrate.

The $5 \mathrm{~m}$ of fine-grained muddy and peaty deposits, that represent a long period of lowenergy deposition, are interrupted by 3 coarsegrained layers indicative of high energy deposition. Similarly to Lesina Lake, we interpret these disturbance layers as possible evidence of three tsunamis. The two uppermost disturbance layers are exposed at both sites in irrigation ditches (fig. 11). We refer to the events that deposited these 3 disturbance layers as Events S1-3, with numbers increasing with age and depth.

The upper layer («Event S1 layer») occurs at depths of 40-60 cm, typically just at or above the contact between the peat and silt. It consists of mixed pockets of tan fine-grained sand, silt, blackish muddy peat, and broken and ground fragments of yellowish tufa, in varying amounts. It most commonly has a sharp lower and a gradational upper contacts and its thickness ranges from $3-15 \mathrm{~cm}$. In 15 of the 27 ditches examined this layer is clearly distinguishable. Radiocarbon dating of a charcoal fragment (sample SIP-D5-RC3 in table I) collected just below this sand indicates that it is younger than 240-420 A.D.

The next layer («Event S2 layer») typically occurs at depths of 70-90 cm, and therefore does not crop out in shallower ditches. It consists of a discontinuous $1-3 \mathrm{~cm}$ layer of fine- to medium-grained, gray sand in sharp contact with the surrounding black peat. This stratum is visible in 5 of the 9 sections studied that are deep enough to extend down into the black peat that typically surrounds it. Two charcoal samples, collected above and below this deposit (samples SIP-D5-RC3 and SIP-D7-RC2 in table I, see fig. 11) yield radiocarbon dates that bracket its age between 320 and 420 A.D. At the Siponto site, ditch 1, two fragments of pottery lie at a depth of $70 \mathrm{~cm}$. Local archaeologists from the Foggia Regional Department date them between 400 and 1200 A.D. based on the style of pottery, with the older part of the interval preferred. The stratigraphic relationship between the shards and the middle disturbance layer is unclear, because neither of the upper two disturbance layers was present in the stratigraphy where the pottery was found. How-
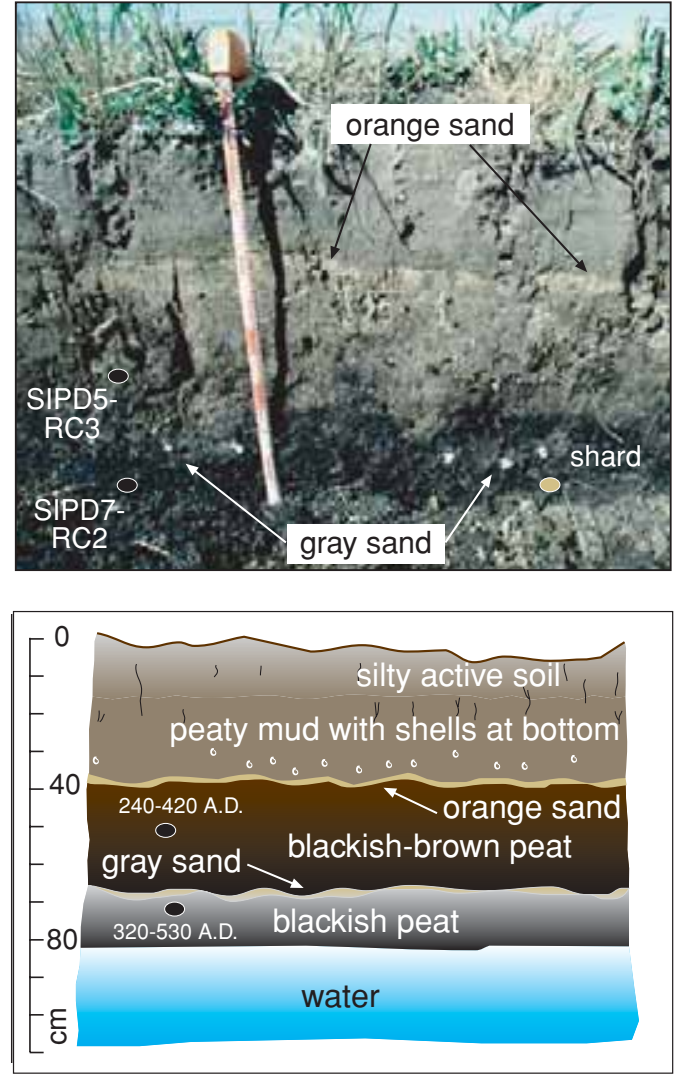

Fig. 11. Siponto site: picture of the two tsunami sands from ditch 5 (above) and simplified sketch of the upper $1 \mathrm{~m}$ of stratigraphy studied in the ditches (below). The location of two charcoal samples and of the shard is also plotted with a black circle.

ever, the depth of the shards and their stratigraphic relationship to the peat and silt imply they were deposited before the last two disturbance events. This archaeological estimate agrees with the radiocarbon ages (samples SIPD5-RC3 and SIP-D7-RC2 in table I) reported above and further constrains the timing of Event S2.

The third layer («Event S3 layer», figs. 9b and 12) consists of normally graded fine- to medium-grain tan sand. Sand grains are well rounded and the layer contains no mud in the interstices. It sharply overlies brown peat and 


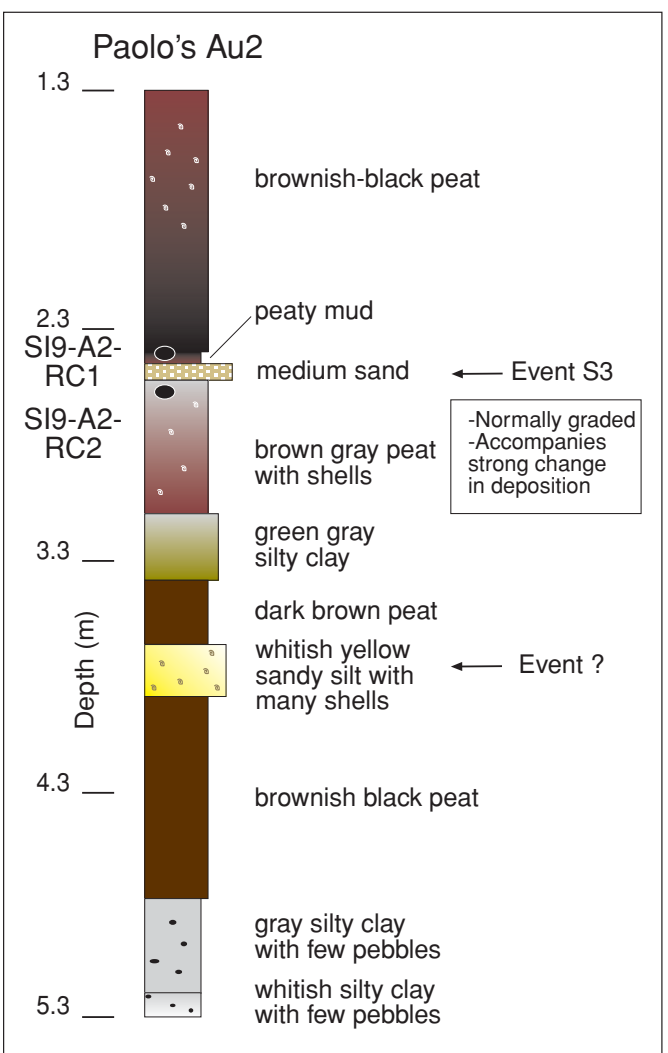

Fig. 12. Core Paolo's AU2 log from Siponto area. The location of two charcoal samples is also plotted with a black circle.

underlies peaty mud in a gradational contact (figs. $9 \mathrm{~b}$ and 12). This layer occurs at about 250 $\mathrm{cm}$ below the surface and is only visible in gouge cores. Over a $900 \mathrm{~m}^{2}$ area it is found in all 8 cores that penetrated to this depth. Dating of charcoal fragments (samples SI9-A2RC1 and SI9-A2RC2 in table I) collected above and below it constrains the age of this layer to the interval 2130-1430 B.C.

\section{Micropaleontological analysis}

As discussed above, historical and modern tsunamigenic deposits frequently include sand and/or other material. Micropaleontology has been used in several studies to characterize the provenance of anomalous sand layers and their depositional environment (Minoura et al., 1994; Hemphill-Haley, 1996; Nelson et al., 1996; Hutchinson et al., 1997). This tool may help identify marine surges into freshwater ponds or lakes by detecting marine species in an otherwise freshwater environment.

We collected samples of sand from disturbance layers and surrounding material at Lesina Lake and Siponto. Selected samples were then washed and sieved into three sizes, 125-250, $250-500$ and $>500 \mu$. Material from the 250$500 \mu$ fraction was then analyzed under a binocular microscope with foraminifera, ostracods and plant matter being picked, sorted into species and counted.

\subsection{Lesina Lake area}

We analyzed samples from two sites we deemed to best represent the stratigraphy at Lesina Lake, Black Panther and Tamaricelle. In this preliminary phase, we limited our analysis to the sand layers deposited by Events L1 and $\mathrm{L} 3$, as these were the most widespread. Microfossil assemblages from the «Event L1 sand» in the two cores were nearly identical; likewise, microfossil assemblages from the «Event L3 sand» were nearly identical between cores, reinforcing our stratigraphic correlation.

Event $L 1$ - The samples examined consist of light brown silty sand, containing fragments of rearranged marine shells. The inorganic fraction consists of carbonate concretions and rare crystals of gypsum. Microfauna assemblages are abundant and well preserved (more than 90\% intact) and a restricted fauna of both foraminifera and ostracods is present. Frequent gastropods are also visible (Valvata piscinalis). The foraminifera, purely freshwater, are almost completely dominated by Ammonia parkinsoniana (parkinsoniana) (about 90\%) with Ammonia parkinsoniana (tepida) (about $8 \%$ ) and minor (< $1 \%$ ) Haynesina germanica, Elphidium granosum, Elphidium sp., Aubigyna perlucida also present. 
The ostracod assemblage displays slightly more variation and includes the brackish species Xestoleberis communis, Cyprideis torosa, Loxoconcha elliptica, Leptocythere castanea. These species indicate peripheral marine conditions. Cyprideis torosa is especially adaptable to diverse salinity, from almost freshwater to over 60 parts per thousand; Loxoconcha elliptica is totally confined to brackish conditions. All shells are well calcified and irregular ones are rare.

The characteristics of both foraminifera and ostracods assemblages, certainly autochthonous, refer to a saltmarsh environment. The lack of evidence of ecological stress would suggest an environmental stability.

Event L3 - The samples consist of gray sand, containing fragments of rearranged marine shells. The inorganic fraction contains frequent carbonate incrustations on plants, some rare crystals of gypsum and mica. In terms of microfauna, the assemblages are abundant and well preserved (more than 90\% intact) and a limited fauna of both foraminifera and ostracods is present. Frequent mollusks are present (Valvata piscinalis, Gyraulus laevis, Ancylus sp.). The foraminifera, purely freshwater, are almost completely dominated by Ammonia parkinsoniana (parkinsoniana) (about 90\%) with Ammonia parkinsoniana (tepida) (about 8\%), Aubigyna perlucida (about 3\%) and minor $(<1 \%$ ) Haynesina germanica and Elphidium sp. also present. The foraminifera assemblages show the presence of frequent deformed specimens and a high intraspecific variability, a sign of ecological stress probably due to environmental instability. The ostracods assemblage contains the brackish species Xestoleberis communis, Heterocypris salinua, Candona sp., Herpetocypris chevreuxi. All these species are strictly continental. The presence of many ostracods with closed valves and of foraminifera with very thin shells absolutely intact implies a depositional environment with low energy, in which the conditions were more or less constant. Carophitae oogones are frequent, intact and well preserved, their presence indicates a low energy depositional environment, clearly continental.

In general, the results of the micropalaeontological analysis, performed on samples from the Lesina Lake area, suggest that the deposits are typical of a brackish environment (saltmarsh), almost totally cut off from normal marine conditions. This is particularly true for the «Event L3» layer. The presence of coarse sand with fragments of bivalve marine shells, typical of an environment with higher energy, sedimented in a quiet environment, indicates a certain degree of rearrangement, possibly due to tsunami waves.

\subsection{Siponto area}

We analyzed samples from the «Event S1 sand layer» collected from ditch exposures at Mr. Paolo site, and from the «Event S3 sand layer» collected from gouge core at Mr. Paolo site (fig. 10).

Micropalaeontological analysis of the «Event S1 sand layer» revealed faunal assemblages very similar to those observed in the $\ll \mathrm{E}$ vent L1» deposit at Lesina Lake area (see Section 4.1.). Foraminifera assemblages from this layer are typical of a brackish environment with a minor presence of marine species. Some wellpreserved fresh water ostracods were identified and few specimens with spotted decalcified shells were observed. Spotted decalcification may be indicator of episodic acidic changes.

Detailed analysis of the «Event S3 sand layer» reveals it is very rich in limonite but sterile, lacking both microfauna and flora. Thus we can not make any inference on the possible tsunamigenic origin of this sand layer.

\section{Discussion}

The occurrence of several historic earthquakes and evidence for multiple tsunamis in the Gargano region, most notably those in 1627, clearly highlight that earthquakes and tsunamis comprise a large portion of the geologic hazard in this area. Significant components of the hazard evaluation include tsunamis and liquefaction recurrence, the areas affected by them and the magnitude of their effects. In the following we discuss the interpretation of our findings in terms of: a) distribution of liq- 
uefaction features probably related to the 1627 earthquake on the Northern Gargano coast, and b) recurrence and distribution of anomalous sand layers, interpreted as tsunami deposits, both north and southeast of the promontory.

\subsection{Liquefaction evidence at the Fortore mouth and at the Lesina Lake}

The convoluted layer and sand dike in the Fortore River estuary is most likely the result of earthquake-induced liquefaction. Obermeier (1996) suggests clastic dikes present the most convincing evidence for seismic liquefaction. The association of the convoluted layer with the sand dike suggests the convoluted layer shares the same origin. Convolutions and clay clasts probably resulted from water and sand flowing horizontally within the layer during seismic shaking, and ripping clasts from the surrounding material. Although no absolute age is available from the ditch wall, the upper termination of the sand dikes (fig. 5), 5 to $10 \mathrm{~cm}$ below the surface suggests that the correlation of these features with the earthquake of July 30 1627, the strongest recent earthquake in the region, is reasonable.

We have two working hypotheses for the formation of the convoluted layer at Lesina Lake site. It contains features common in liquefied sand layers (i.e. convolutions), but it lacks definite evidence for liquefaction (i.e. sand dikes). Another hypothesis is that when the 1627 earthquake hit, this area was covered with shallow lake water, as suggested by the current position of the ground surface below the lake level. Either the tsunami that followed the earthquake or seiches in the lake caused a disturbance that affected this layer. The radiocarbon age of the sample LD207 (table I), collected from the top of the convoluted layer, implies this horizon was deposited between 1450 A.D. and 1640 A.D., allowing either hypothesis.

\subsection{Tsunami evidence at the Lesina Lake and Siponto area}

The suspected tsunami deposits (figs. 8, 11 and 12) examined in the Lesina Lake and at
Siponto contain coarser grained material, usually normally graded, than the deposits above and below them, have often sharp basal contacts and occasionally include clasts of mud and peat. The presence of sand in all these layers implies deposition from higher energy flow than the surrounding material. Normal grading in the sand layers implies deposition from suspension, as expected from a tsunami which entrains sand from the beach as it passes, and carries it in suspension as the flow progresses inland. The sharp contacts imply a sudden inundation rather than a gradual transition to a higher energy environment, consistent with the inundation expected for a tsunami. Moreover, the abundance of fragments of marine shells in these layers suggests they were mechanically broken while being transported in a violent flow. All of these traits are common in tsunami deposits, and have been used as criteria for distinguishing a tsunami deposit (Clague et al., 1994; Atwater et al., 1995; Atwater and Hemphill-Haley, 1997; Benson et al., 1997).

\subsection{Lesina Lake area}

The uppermost sandy layer (fig. 8), «Event L1» has to be younger than 1440-1890 A.D. (sample LE2) where the lower part of the time interval is statistically preferred (see table I). We also expect the event age to be possibly very close to the age of the sample considering its stratigraphic position and an uninterrupted sedimentation at the site, thus suggesting a probable origin from the 1627 tsunami. The «Event L2» sand (fig. 8) accompanies transition from marsh peat (below) to gray silty mud (above). This pattern is common for tsunami deposits found on the Cascadia Subduction Zone, where it is most commonly attributed to the sudden coseismic subsidence of a marsh surface into the intertidal zone (Darienzo and Peterson, 1990; Atwater et al., 1995; Atwater and Hemphill-Haley, 1997). The marsh plants are then killed by exposure to more saline water and buried by intertidal mud. This pattern has also been seen associated with tsunami deposits in coastal freshwater lakes (Hutchinson et al., 1997; Garrison-Laney, 1998) and coastal fresh- 
water marshes (Witter and Kelsey, 1996). In these cases the marsh may have been killed by the incursion of saline water from the tsunami, an earthquake-induced change in the morphology of the marsh and beach, or buried by increased sedimentation after the earthquake and tsunami.

Preliminary micropalaeontological analysis of the «Event L1» and «Event L3» sand layers does not give unequivocal constraints for interpreting these layers as tsunami deposits. As previously discussed, the microfauna, mainly foraminifera and ostracods, observed in the examined layers is typical of saltmarsh environment and the presence of several intact very thin shells suggests a low energy depositional setting. This intact and fragile microfauna could not have been in place at the time of the deposition of the coarse sands and the broken bivalve shells. The co-existence of sediments indicative of high energy and microfauna indicative of low energy conditions, in our opinion, can only be explained by an imprecise sampling procedure. Sand layers observed in the field frequently have sharp basal contacts with high concentrations of broken marine shells. Gradational upper contacts make the inadvertent selection of some overlying material sometimes unavoidable. An interesting observation is the total absence of marine microfauna. While this may not have been expected, it is not unique. In fact, micropalaeontological analysis of paleotsunami deposits in fresh water environments show the vast majority of microfossils included in these deposits are fresh to brackish water species (Minoura et al., 1994; HemphillHaley, 1996; Nelson et al., 1996; Hutchinson et al., 1997; Garrison-Laney, 1998). Clearly, further study including careful sampling of sand layers and their surrounding sediments is necessary to answer these questions.

The sources responsible for the earthquakes that produced the three tsunami waves remain uncertain. Tinti and Piatanesi (1996) performed numerical simulations of the 1627 earthquake and tsunami, integrating shallow water equations via a finite elements technique and assuming dip-slip faults placed in different locations and with various strike both on land and offshore. These authors suggest that the possible source responsible for the 1627 tsuna- mi is a fault placed inland along the coastal area enclosing the Lesina Lake and the mouth of the Fortore river, that caused the uplift of the sea floor facing the Gargano promontory. We were not able to find evidence of such fault, but we have to consider that this area is dominated by littoral sand dunes and active river channels, that are able to modify the morphology quite rapidly. The age of the lower tsunami deposits («Event L2» and «Event L3») is not within the historical record and we cannot infer a triggering source for these potential tsunamis. Other possible sources include the Tremiti Fault System, located $25 \mathrm{~km}$ offshore to the north, or seismogenic faults on the Eastern Adriatic Sea border. In this frame, it has to be underlined that the coasts of Albania and Montenegro experienced, in the last two millenniums, a relevant number of tsunamigenic events, particularly in the region of Valona. Two recent ones, occurred respectively in 1920 at Saseno Island and in 1979 in Kotor Bay, have been destructive, causing severe damage and victims along the Eastern Adriatic coasts. Moreover, both these events produced sea perturbations also observed and /or recorded along the Italian coasts as in the tide gauge of Bari (Bedosti and Caputo, 1986). On this basis, we suggest an inundation average recurrence interval of about 1700 years. If we could infer that all 3 tsunamis affecting that site were triggered by earthquakes on the same source responsible for the 1627 shock, we could obtain a minimum average recurrence interval of about 1700 years for that fault.

\subsection{Siponto area}

Although the disturbance layers at Siponto have more features common in tsunami deposits than those at Lesina Lake (all three contain sand, one has rip-up clasts, one has normal grading), the interpretation of tsunami as the depositional mechanism at Siponto is less strong because the morphology of the site has changed significantly in the last 2000 years. In fact, the morphology and position of the beach berm 2000 years ago, and thus the approach of the hypothesized tsunami flow is less clear than 
at Lesina Lake area, where the lake probably retained nearly the same morphology as it has today.

The only historically documented tsunami near the site was associated with the 1627 earthquake. During this event, anomalous waves rose as high as $2.5 \mathrm{~m}$ on the walls protecting the city of Manfredonia.

Micropalaeontological analysis of samples of the uppermost sand (fig. 11), collected from the ditches at the Siponto and Mr. Paolo sites, reveals the presence of both foraminifera and ostracods typical of brackish environments, together with minor marine species. Samples of the «Event S3 sand layer» (figs. 9b and 12), unfortunately lack of any microfossils. Again, analysis of microfossils does not substantiate the interpretation of a tsunamigenic derivation for these deposits. Nonetheless, based on characteristics of the three disturbance layers themselves and the tectonic activity of the region, we suggest a tentative interpretation as tsunami deposits is still valid.

We do not have direct evidence for locating the sources of earthquakes that triggered the three tsunami deposits found in the Siponto area. In general, the Mattinata Fault System, and particularly its offshore portion, could be considered a possible local source. Similarly at the Lesina Lake area, the strong seismic activity of the Albanian and Montenegro coasts in the Southern Adriatic Sea must be considered as probable farfield sources. The uppermost disturbance layer may be associated with the event in 1627 , but the distance of this site from the probable epicenter of that earthquake, and the historical reports of very localized waves at Manfredonia, with no mention to the Southern Siponto area, make this association tentative at best. Based on these interpretations and considering that no clear historical information exists on local tsunamigenic source, we suggest that the average recurrence time for violent sea inundation at this site is approximately 1200 years.

\section{Conclusions}

The recurrence and distribution of tsunami deposits and liquefaction features in the Gar- gano region have been explored through field surveys of irrigation ditch walls and gouge cores. In doing this, we studied the upper $5 \mathrm{~m}$ of stratigraphy in three marsh areas on the northern and southeastern coasts of the promontory.

We identified clear evidence of liquefaction near the mouth of the Fortore River and close to the eastern edge of Lesina Lake. Based on the upper termination of sand dikes rising to 5-10 $\mathrm{cm}$ of the surface and the age of a charcoal sample (1450-1640 A.D.; LD 207 in table I) collected from the top of a liquefied sand layer, we claim to have found features related to the 1627 earthquake, for which numerous liquefaction effects have been reported by contemporary chronicles.

Based on field observations and the constraints given by radiocarbon dating of selected samples, we believe we have identified evidence in the gouge cores for three tsunamis that inundated Lesina Lake and three that submerged the town of Siponto. We must emphasize that this interpretation is preliminary and reflects our current level of uncertainty. In particular, while detritus of marine macrofossils have been found in the coarse sand samples, micropalaeontological analysis reveals assemblages typical of brackish environment and does not provide unequivocal constraints to a tsunamigenic cause.

In the Lesina Lake area, the uppermost disturbance layer identified in gouge cores has a minimum age of 1440-1890 A.D., where the lower part of the time interval is statistically preferred (LE2, table I). Taking into account the historical reports and this age, we suggest an origin from the 1627 tsunami for this sand layer. Two radiocarbon dates (TM5-RC2, TM5-RC3 in table I) constrain the deposit of the oldest sand between 3630-3350 B.C. Thus, a conservative interpretation provides a minimum average recurrence interval of about 1700 years for tsunami inundation in this area. If the paleotsunamis are related to the same fault responsible for the 1627 earthquake, this average recurrence interval may be typical for that source.

In the Siponto area, archeological and radiocarbon (SIP-D5-RC3, SIP-D7-RC2 in table I) ages indicate that the two upper disturbance layers were deposited in historical time. Dating of charcoal fragments (samples SI9-A2RC1 and 
SI9-A2RC2 in table I) constrains the age of the oldest sand layer to the interval 2130-1430 B.C. Accordingly, the average recurrence time for violent sea inundation at this site is approximately 1200 years.

At present, age constraints are not enough to discuss possible correlation between inundation events occurred along the northern and southeastern coasts of the Gargano promontory.

\section{Acknowledgements}

We are grateful to two anonymous reviewers for valuable comments and suggestions that improved the clarity and focus of the manuscript. We wish to thank F. Frugoni (INGV), A. Piatanesi (INGV) and M. Rymer (USGS) for the interesting discussions on tsunami generation and their field identification. We are also indebted with Mr. S. Persichetti of Laboratorio Preparazione Rocce e Sedimentologia (Università degli Studi Roma Tre) for his valid support during the preparation of the samples.

\section{REFERENCES}

AmbRASEYS, N.N. (1962): Data for the investigation of the seismic sea-waves in the Eastern Mediterranean, Bull. Seismol. Soc. Am., 52 (4), 895-913.

ANDERSON, H. and J. JACKSON (1987): Active tectonics of the Adriatic region, Geophys. J.R. Astron. Soc. 91, 937-983.

ANTINORI, A.L. (1782): Raccolta di memorie istoriche delle tre provincie degli Abbruzzi, Napoli, 4 vols.

Atwater, B.F. and E. HemphiLl-Haley (1997): Recurrence intervals for great earthquakes of the past 3500 years at Northeastern Willapa Bay, Washington, U.S. Geol. Surv Prof. Pap. 1576, pp. 108 .

Atwater, B.F., A.R. Nelson, J.T. Clague, G.A. Carver, D.K. YAMAGUChI, P.T. BobrowsKy, J. BourgeoIs, M.E Darienzo, W.C. Grant, E. Hemphill-Haley, H.M. Kelsey, G.C. Jacoby, S.P. NishenKo, S.P. PALMER, C.D. Peterson and M.A. Reinhart (1995): Summary of coastal geologic evidence for past great earthquakes at the Cascadia subduction zone, Earthquake Spectra, 11, 1-18.

BALlERANI, M. (1627): Caso grandissimo occorso nel presente anno 1627 dove si sentono terremoti, e ruine con morte di migliaia di persone, che pareva proprio il giudizio universale, essendosi sommerse in Puglia da 9 lochi principali, Lanciano-Iesi.

BARATTA, M. (1901): I Terremoti d'Italia (Le Monnier, Torino), pp. 950

Bedosti, B. and M. CAPUTO (1986): Primo aggiornamento del
Catalogo dei Maremoti delle coste Italiane, Atti Accad. Naz. Lincei Rendiconti, serie 8, LXXX, 570-584.

Benson, B.E. K A Grimm and J J. Clague (1997): Tsunami deposits beneath tidal marshes on Northwestern Vancouver Island, British Columbia, Q. Res., 48, 192-204.

Boschi, E., E. Guidoboni, G. Ferrari, D. Mariotti, G. VALENSISE and P. GASPERINI (2000): Catalogue of strong Italian earthquakes from 461 B.C. to 1997, Ann. Geofis., 43 (4), 607-868 (with CD-ROM).

BourgeoIs, J. and M.A. REINHART (1989): Onshore erosion and deposition by the 1960 tsunami at the Rio Lingue estuary, South-Central Chile, Eos, Trans. Am. Geophys. Un., 70 (43), 1331

Cerqua, G.J. (1627): Lettera di Giovanni Jacono Cerqua, Lucera 8 Agosto 1627, quoted in Ragguaglio del terremoto successo in Puglia à 30 Luglio 1627, Roma.

Checchia Rispoli, G. (1916): I terrazzi dellle pendici meridionali del Gargano, La Geografia, IV (4-7), 255-259.

Chilovi, C., A. De Feyter and A. Pompucci (2000): Wrench zone reactivation in the Adriatic Block: the example of the Mattinata Fault System (SE Italy), Boll. Soc. Geol. It., 119, 3-8.

Clague, J.J., P.T. Bobrowsky and T.S. Hamilton (1994): A sand sheet deposited by the 1964 Alaska tsunami at Port Alberni, British Columbia, Estuarine Coastal Shelf Science, 38, 413-421.

Console, R., R. Di Giovambattista, P. Favali and G. SMRIGLIO (1989): Lower Adriatic Sea seismic sequence (January 1986): spatial definition of the seismogenic structure, Tectonophysics, 166, 235-246.

Console, R., R. Di Giovambattista, P. Favali, B.W. Presgrave and G. Smriglio (1993): Seismicity of the Adriatic microplate, Tectonophysics, 218, 343-354.

CPTI Working Group (1999): Catalogo Parametrico dei Terremoti Italiani (ING-GNDT-SGA-SSN, Bologna), pp. 88 (http://www.ingv.it/).

Darienzo, M.E and C.D. Peterson (1990): Episodic tectonic subsidence of Late Holocene salt marshes, Northern Oregon, Central Cascadia margin, Tectonics, 9 (1), 1-22.

Dawson, A.G., D. Long, D.E. SмiтH, S. SHI and I.D.L. Foster (1991a): Tsunamis in the Norwegian Sea and North Sea caused by the Storegga Submarine Landslides, in Proceedings of the Symposium on Tsunamis, International Union of Geodesy and Geophysics, Vienna.

Dawson, A.G., I.D.L. Foster, S. ShI, D.E. Smith and D. LONG (1991b): The identification of tsunami deposits in coastal sediment sequences, Science of Tsunami Hazards, 9(1), 73-82.

Dawson, A.G., R. Hindson, C. Andrade, C. Freitas, R. PARISH and M. BATEMAN (1995): Tsunami sedimentation associated with the Lisbon earthquake of November the 1st 1755 A.D.: Boca do Rio, Algarve, Portugal, The Holocene, 5 (2), 209-215.

De PoARd, G.V. (1627): Nuova relazione del grande $e$ spaventoso terremoto successo nel Regno di Napoli, nella Provincia di Puglia, in venerdi li 30 Luglio 1627, Roma.

DogLIONI, C. (1994): The Puglia uplift (SE Italy): an anomaly in the foreland of the Apenninic subduction due to buckling of a thick continental lithosphere, Tectonics, 13, 1309-1321.

Favali, P., G. Mele and G. Mattietti (1990): Contribution to the study of the Apulian microplate geodynamics, Mem. Soc. Geol. It., 44, 71-80. 
Favali, P., R. Funiciello, G. Mattietti, G. Mele, P. Montone, F. SAlvini and M. Tozzi (1992): Seismotectonic identity of the Southern Adriatic area, in Contributions to the Geology of Italy with Special Regard to the Paleozoic Basements, edited by L. CARMIGNANI and F.P. SASSI, IGCP n. 276, Newsletter vol. 5, Siena, 339-343.

Favali, P., R. Funiciello, G. Mattietti, G. Mele and F. SALVINI (1993): An active margin across Adriatic Sea (Central Mediterranean Sea), Tectonophysics, 219, 109-117.

FinETTI, I. (1984): Structure and evolution of the Adriatic microplate, Boll. Ocean. Teor. Appl., 2, 115-123.

FINETTI, I. and C. MoRELLI (1973): Geophysical exploration of the Mediterranean Sea, Boll. Geofis. Teor. Appl., 15(60), 263-341.

GALLI, P. and F. Meloni (1993): Nuovo catalogo nazionale dei processi di liquifazione avvenuti in occasione dei terremoti storici in Italia, Il Quaternario, 6 (2), 271-292.

GARRISON-LANEY, C. (1998): Diatom evidence for tsunami inundation from Lagoon Creek, a coastal freshwater pond, Del Norte county, California, M.S. Thesis, Department of Geology, Humboldt State University.

HempHILl-Haley, E. (1996): Diatoms as an aid in identifying Late-Holocene tsunami deposits, The Holocene, 6 (4), 439-448.

Hutchinson, I. JJ C Clague and R.W. Mathewes (1997): Reconstructing the tsunami record on an emerging coast: a case study of Kanim Lake, Vancouver Island, British Columbia, Canada, J. Coastal Res., 13 (2), 545-553.

ING (1991): Catalogue of the Italian Earthquakes from 1450 B.C. to 1990 A.D., Rome (internal file).

LORT, J. M. (1971): The tectonics of the Eastern Mediterranean: a geophysical review, Rev. Geophys. Space Phys., 9, 189-216.

Mantovani, E., D. BABbucci and F. FARsi (1985): Tertiary evolution of the Mediterranean region: outstanding problems, Boll. Geofis. Teor. Appl., 26, 67-88.

Mantovani, E., D. Albarello, D. Babbucci and C. TAMBURELli (1993): Post-Tortonian deformation pattern in the Central Mediterranean: a result of extrusion tectonics driven by the Africa-Eurasia convergence, in Recent Evolution and Seismicity of the Mediterranean Region, edited by E. Boschi, E. Mantovani and A. Morelli (Kluwer Academic Publishers, Dordrecht), NATO ASI Series, Series C: Mathematical and Physical Sciences, 402, 65-104

McKenzIE, D. (1972): Active tectonics of the Mediterranean region, Geophys J. R. Astron. Soc., 30, 109-185.

Minoura, K., S. NAKAYA and M. UCHIDA (1994): Tsunami deposits in a lacustrine sequence of the Sanriku coast, Northeast Japan, Sediment. Geol., 89, 25-31.

Minoura, K., V.G. Gusiakov, A. Kurbatov, S. Takeuti, J.I.
Svendsen, S. BondeviK and T. OdA (1996): Tsunami sedimentation associated with the 1923 Kamchatka earthquake, Sediment. Geol., 106, 145-154.

Nelson, A.R., H.M. Kelsey, E. Hemphill-Haley and R.C. WITTER (1996): A 7500-years lake record of Cascadia tsunamis in southern coastal Oregon, Geol. Soc. Am. Abstracts with Programs, 28 (5), 95.

OBERMEIER, S.F. (1996): Using liquefaction-induced features for paleoseismic analysis, in Paleoseismology, edited by J.P McCALPIN (Academic, San Diego, CA), 331-396.

OBERMEIER, S.F. and E.C. POND (1999): Issues in using liquefaction features for paleoseismic analysis, Seismol. Res. Lett., 70, 34-58.

PICCARDI, L. (1998): Cinematica attuale, comportamento sismico e sismologia storica della faglia di Monte Sant'Angelo (Gargano, Italia): la possibile rottura superficiale del «leggendario» terremoto del 493 D.C., Geogr. Fis. Din. Quat., 21, 155-166.

PostPISCHL, D. (Editor) (1985): Catalogue of the Italian earthquakes from 1000 to 1980, Quad. Ric. Sci. (PFG-CNR, Bologna), 114 (2B), pp. 239.

RCMT (2002): European-Mediterranean Regional CentroidMoment Tensors Catalogue (http://www.ingv.it/seismoglo/RCMT/).

SAlvini, F., A. Billi and D.U. Wise (1999): Strike-slip faultpropagation cleavage in carbonate rocks; the Mattinata Fault Zone, Southern Apennines, Italy, J. Struct. Geol., 21 (12), 1731-1749.

SieberG, A. (1930): Geologie der Erdbeben, Handbuch der Geophysik, 2 (4), 550-555.

Stuiver, M., P.J. Reimer, E. Bard, J.W. Beck, G.S. Burr, K.A. Hughen, B. Kromer, F.G. McCormac, J.V.D. Plicht and M. SPURK (1998a): INTCAL98 Radiocarbon age calibration 24000-0 cal BP, Radiocarbon, 40, 10411083.

Stuiver, M., P.J. ReIMER and T.F. Braziunas (1998b): Highprecision radiocarbon age calibration for terrestrial and marine samples, Radiocarbon, 40, 1127-1151.

TinTI, S. and A. PIATANESI (1996): Numerical simulations of the tsunami induced by the 1627 earthquake affecting Gargano, Southern Italy, J. Geodynamics, 21, 141-160.

Tinti, S., A. Maramai and L. Graziani (2002): The new catalogue of the Italian Tsunamis, J. Seismol. (submitted).

VAlensise, G. and D. PANTosti (Editors) (2001): Database of potential sources for earthquakes larger than $M 5.5$ in Italy, Ann. Geofis., 44 (suppl. to n. 4), pp. 183 (with CDROM).

WitTER, R.C. and H.M. Kelsey (1996): Repeated abrupt changes in the depositional environment of a freshwater marsh: a record of Late Holocene paleoseismicity at Euchre Creek, south coastal Oregon, Geol. Soc. Am., Abstracts with Programs, 28, 125. 